\title{
SELF-EMPLOYED URBAN WOMEN : CASE STUDIES FROM BAMAKO*
}

\author{
Mariken Vaa \\ Institute for Social Research, Oslo, Norway
}

\section{WOMEN'S WORK}

In most countries, labour force statistics, national accounts and censuses reflect a gross underestimation of women's participation in economic activity. The reasons for this are several. They may be ideological, in the sense that women's work is seen as secondary and subordinate to that of men, or reflect the fact that such an important part of women's work is unpaid and takes place within the household. Biases may be further reinforced by conceptual shortcomings in the categories used and/or in deficient understanding of them by data collecting agents and by respondents. Sometimes, the data collection procedures lead to deficient information. Information is usually sought with male heads of households, but in some cultures, men's and women's economies are compartmentilized in such a way that the men have little possibility of supplying reliable information about the economic activities of women. Over the last couple of decades, these problems have received increasing attention from scholars, women's organizations and various national and international agencies. (See for instance Antoine \& Traoré 1985, Beneria 1981, Charmes 1985, Keita 1981). But the various recommendations and

* Based on a research project financed by the Norwegian Ministry of Development Cooperation/Norwegian Council for Applied Social Research. Institutional affiliation in Mali is to Institut des Sciences Humaines, Bamako. The data presented here were collected in cooperation with Sally Findley, CERPOD and Assitan Diallo of ENSUP, Bamako. I want to thank them, as well as Gunhild Hagestad, Oslo, for useful comments on an earlier version of this paper. 
guidelines which have been offered are slow in gaining acceptance, and much remains to be done with respect to making women's role more visible and realistically assessing their contribution to household survival and national production. This is particularly true of poor women in peripheral economies.

We have to turn to special studies of women's work to get a true picture of what they actually do. In a number of African countries, in depth case studies of women's work and life conditions have already been conducted (Obbo 1980, O'deye 1985, Oppong 1983). There is a steadily growing literature on women and development, and a more uneven trickle on women in the informal sector. But for particular cities, information may be very thin.

Bamako, the capital of Mali, is a case in point. A recent analysis of the situation of women and children in Mali, undertaken by UNICEF (1989), has more than 300 publications listed in the bibliography, but only an handful refer to urban women. Of particular interest for urban women's work roles is a study of traders on the Bamako - Dakar railway (Lambert de Frondeville, 1987), and a report on housemaids in Bamako (ISH 1984). But again, official statistics tell us very little about the economic role of women. The 1976 Census, as well a World Bank survey from 1983 put the proportion of women in the working population of Bamako at 18 per cent (PUM 1984:32)(1). In both instances, it seems that mainly those women who are employed in formal sector activities in the city are counted as being economically active, which certainly gives a misleading picture. On a national basis, traditional commerce, the sector outside agriculture in which most women are engaged, is not even included in economic statistics (Keita 1981).

\section{THE SETTING}

The cost of living in Bamako compared to the extremely low level of wages indicate that many families somehow have "hidden" sources of livelihood. Traditionally, West African women play an important role as providers, through food production. In the cities, at least in the poorer strata, they are likewise faced with the necessity of contributing to the household economy. Although urban men ideally are expected to provide fully for their families, the rality often falls short of the ideals. The norm seems to be that the husband should at least pay for housing, taxes and medicine, buy staple food and give his wife a daily sum for sauce to go with the cereals. Clothes for herself and her children, money for gifts and other expenses often become the woman's responsibility. In practice, men often fail to come up with sufficient money for food and medicine, and it is up to the women to secure that the family eats every day. Women without any professional skills have difficulties in finding employment in the formal wage sector. They have to rely on their own resources, friends and family in order to find activities that may produce income. These activities are often invisible in a double sense of the word. They are not only unrecorded by statisticians and unrecognized by most husbands, at least their full economic importance. In many cases, the boundary between women's unpaid domestic labour and the tasks they perform to create incomes is often fluid. 
74.

This paper presents data from a research project on women in a poor Bamako neighbourhood. The main emphasis is on their short and long term strategies to secure survival for themselves and their dependents. The project is still in progress, and the presentation here is limited to four women and their backgrounds, family situations and economic activities.

The area where the women live is a large, unauthorized settlement which emerged during the last 25 years, and which is now housing more than 50.000 people. It is located about 8 kilometers from the center of Bamako. A large proportion of the residents are recent migrants to town. Rents are cheaper here than in legal and more central neighbourhoods, but housing quality is lower, water supply is uncertain, sewage non-existent and there is no electricity. Income levels are varied, but lower than the city average. The most recent data on incomes are from the 1983 World Bank survey mentioned above, where the mean monthly income per household in the city as a whole was estimated to be 62.000 FCFA (100 FCFA $=2$ Fr.F), ranging from 157.000 in the residential neighbourhoods to only 40.000 in the unauthorized settlements. This may give some idea of income differentials, but the figures themselves are of dubious value. The statistician's definition of household may not capture Bamako realities, and it is more than doubtful that the survey has managed to get information on all income-generating activities. As we shall see, households take many forms, and incomes are sought in a variety of ways.

\section{MAKING ENDS MEET: FOUR CASE STUDIES}

My current fieldwork aims at exploring strategies used by women who live in urban poverty for making ends meet. More details about conceptual framework and methodology, may be found in Vaa (1987) and Vaa, Diallo and Findley (in press). In this paper, I will present sketches of four women who through simple means manage to create incomes for themselves and their families. Data were gathered through interviews with the women themselves, at several points, and day-long observation in their compounds. The focus here is on the amount of time they spend on income-generating activities, the various processing operations they perform, their sales, expenses and profits. Using tools and networks on their everyday lives, they engage in processing and sales activities which result in variable, but sizable contributions to their families' living. Although at least three of these women would not have been counted in standard statistics on employment and income, we shall see that they certainly are economically active. In one case, the woman earns almost the average estimated family income per month, at least for parts of the year, but she would not appear in any official statistics. 
75.

\section{A: Food, calebashes and laundrv}

A is 36 years old, she is married to a tailor, and has five children. Two teen-agers and a baby live at home, and two daughters are fostered by her aunt and mother respectively, to help them and keep them company. $A$ and her husband were both born in Bamako, but their parents all came to the city as adults. $A$ has one co-wife, who has four children, all quite small. They all live in the husbands' family compound, together with the father-in-law and his two wives, and an elder brother-in-law and his wife and children. A.'s father-in-law started building here in 1970, but he has no legal title to the land. The three daugthers-in-law take turns cooking for everybody, 21 people in all, plus visitors. Most of the food expenses are covered by the men, but the women who have incomes all make daily cash contributions towards the family meals.

Most mornings throughout the year, from 8 until noon, find $A$ at the neighbourhood market. In school holidays, her eldest daughter join her. What they sell varies with the season. From the beginning of January through April - the main vegetable season in Bamako -, A's principal economic activity is the buying and selling of cabbage. In the afternoon, she buys 20-30 heads of cabbage from a grower, transports them to her fathers' house and cleans them, cuts each into 10-12 smaller pieces which she lets soak overnight. This work takes approximately one hour. She keeps the same price per piece during the whole morning, but the size of the units varies with the season, i.e. with what she has had to pay herself. If she has only a little cabbage left after her time at the market, this goes into the family pot. If a lot remains, she puts it to soak and starts selling the next morning without getting new supplies. In the afternoons, she sometimes gets customers in her own compound. Her stock never lasts more than 2 days. She has a regular supplier who gives her credit until she has sold all. Her expenses are few, 100 CFA in transport daily, water is free at her father's house and knife, basin for soaking and basket for transport are all part of her household equipment. Although she always sells from the same place at the market, she does not have to pay the daily tax, because she knows the taxcollector.

She pays her supplier 600 FCFA for 10 heads of cabbage, and resells each head for about 200 . Assuming that she on average sells 10 heads per day, which is rather conservative, her monthly sales are 50.000 FCFA, her monthly expenses being 15.000 FCFA for stock and 2.500 for transport, which leaves her with a net profit of 32.500 . Even assuming that a proportion of her goods is con-sumed by the family, she nevertheless has a reasonable income for those four months when cabbage is in season. It should be noted, however, that the concept of "monthly income" is totally foreign to her. What is earned one day is spent again within a short time. She would see no sense in separating outlays for stock and for consumption and call what she has spent on the latter her "income". 
76.

She also sells calabashes and dried fish, which she gets from a small town a couple of hours distance from Bamako. If she can afford the trip, which costs 1.500 CFA, she goes herself. Otherwise, she asks her elder sister, or her mother-in-law, who also are traders, to get supplies for her. Her trade in calabashes is limited to the first five months of the year. This is the season when they are put on sale at the rural markets. She and her daughter polish the calabashes with a metal sponge to make them smooth and ready for use. The dried fish is sold in small heaps at 100 FCFA each. This she sells all year round, depending on whether she has money to buy stock. Her turnover on fish and calabashes is a bit uncertain, but seems to be at least 40.000 CFA per month, of which perhaps 30 per cent is profits. In slackj periods, A takes in laundry, which she does herself in the afternoons, and earns 1000 CFA per lot. She has no plans of addition, $A$ almost daily takes in laundry, which she does herself in the afternoons, and earns 1.000 FCFA per lot. She has no plans of expanding her operations. Her working day in addition to household chores is between 6 and 8 hours. A also helps her mother-in-law for about an hour daily with her sales activities, this is as a matter of course unremunerated.

A puts 250 CFA daily into a savings society (tontine), and contributes $100-300$ to the family meals. The rest of her earnings goes to pay for goods she has bought on credit at the local market, primarily clothes and shoes for herself and her children, and household equipment. Gifts and ceremonies are also important items in her expenses.

\section{B : Making little out of almost nothing}

Now 48 years old, $B$ came to Bamako with a baby son when she was 18 to enlist the help of an uncle in getting divorced from her

first husband. She was soon remarried, and has 6 children from her present marriage. Only two are old enough to fend for themselves, the eldest son has gone back to her family to work the land, and a daughter is selling Malian and Mauritanian tie-dye cloth in the Ivory Coast. She stays away for several months at a time. The son is expected to bring back some sacks of millet after the harvesting, and the daughter now and then sends money home for medical expenses and school fees. B tries to keep her children at the Franco-Arabic school, the Medersa. She comes from a devout family of traditional scholars, and wants her children to be able to read and write French and Arabic.

Her husband arrived in Bamako at about the same time she did. He worked for many years as a guard in a shop, but is now retired and has no income. He spends most of his day at his old place of work and at the mosque. In 1974, he acquired the lot for the compound where they live, but he does not have any legal title to it. His first wife and her foster daughter also live there. The two wives are not on good terms, so there is little cooperation between them and they seldom cook for each other. 
B used to sell kola nuts and cloth from a stall in the central market, and was doing quite well, with a large network of suppliers and customers. But she lost all her stock and capital in a robbery, which also left her with a huge debt, for which she was taken to court. Her failing fortune resulted in loss of friends and other people to be relied on for help. She is no longer in a position to give presents to anybody. $B$ is now trying to eke out an income from preparing and selling the cheaper parts of mutton at the neighbourhood market. Every noon, she goes to the big sheep market, which is nearby, and buys 3-6 mutton heads at 300 FCFA a piece, each with three legs included. She has to pay cash, because she has no regular supplier. Other daily expenses than meat are 100-200 for tomatoes, onions and spices and 300 FCFA for firewood. The vegetable she usually pays in cash, but she manages to get the wood on credit because her supplier comes from her home village. She works the whole afternoon at cleaning and scorching, to make the bits ready for cooking. Her daughters of 11 and 15 help her at this. The meat is then put on the boil with spices and vegetables, and is left to simmer through the night. Early the next morning, she goes to the local market and tries to sell this preparation in portions, staying there until noon. The heads sell for 400 FCFA a piece and the legs for 50 . Although she usually sells from the same place at the local market she manages to avoid paying the daily tax. She has no transport costs, since she walks to and from the market. If she manages to prepare and sell an average of 4 heads (with legs) per day, she has in theory monthly sales of $55.000 \mathrm{FCFA}$, and a net profit of 14.500 . In practice, her sales are more irregular and it is not unusual that the only family meal is the

unsold mutton dish. Her working day is at least 11 hours. B finds her present work hard and unrewarding. She would like to go back to the kola and cloth trade, but for that she needs capital. She and her children live in absolute poverty, and she does not see how she can improve her situation.

\section{C: A bit of soap on the side}

C is 22 years old. She is married to a low-level functionary, who earns 34.000 FCFA a month. They have a daughter of 6 and a son of 2 . They are both migrants to Bamako, and lodgers. $C$ considers herself primarily a housewife, but since her husband's income is not sufficient for the family needs, she has recently taken up soap-making to earn some money herself. She has learned this skill from a neighbour. The ingredients are groundnuts, potash and hot water. Up to three times per month, she buys $10 \mathrm{~kg}$ of groundnuts (at $150-175$ FCFA per kilo) and 1 $1 / 2 \mathrm{~kg}$ of potash (at 300 FCFA per kilo) at the local market. She pays cash, because she has no regular supplier. The wares are transported on her head back to the compound, where the preparation takes place. The groundnuts have to be washed, dried and peeled and are then taken to the miller to be ground. She pays him 150 FCFA. The groundnut powder is mixed with hot water and the potash in a big basin. To get the mix right, continuous stirring and pounding for 3-4 hours are required. One also has to be careful, because the potash may burn the skin. The mixture is then shaped into balls, with a cloth protecting the hands. This process takes about 
4 hours net, but the work is often interrupted. She makes $90-100$ balls form each batch, and the size varies a bit with the price of the groundnuts. But the selling price is always the same, 50 FCFA each. $C$ reckons that she has a gross income of $4.500-5.000$ FCFA per batch made from $10 \mathrm{~kg}$ of groundnuts. Her costs are then 2.200 FCFA for ingredients, 150 for the miller and 50 FCFA for firewood. The tools required, such as pot for heating water, basin and wooden spoon for stirring, are part of her ordinary household equipment and not considered as costs. Her husband does not want her to go to the market to sell, so the selling is centered around her own compound. Every morning she sends her little daughter with 5 balls of soap in a bowl to the shopkeeper on the corner, who takes no commission for selling them. Customers also come to her, or more precisely, her daughter brings the message that so-and-so wants a piece of soap, and delivers it to the customer. At the time of the interviews, the couple had also hired a 10 year old housemaid who had come to Bamako to work during the dry season. Her salary was just 2.500 FCFA a month, which was paid by the husband. The maid's duties were mainly laundry, cleaning and cooking, but she also helped with the washing and shelling of the nuts and occasionally went from door to door in the neighbourhood to sell the soap. $C$ has already gained a reputation for making quality soap and has several regular clients. Each batch gets sold in 1-2 weeks, without much effort put into marketing.

Her earnings supplement the daily expenses for food, and she buys clothes and medicine for herself and her children. She also puts money aside for the next batch. To earn $2.000-2.500$ FCFA, she works about ten hours on buying supplies and at processing, and an uncounted number of hours of administering the sale. She would like to expand her operation, but for that she feels she would need an adult (and more expensive) maid to help with the heavy part of the work, and she would have to invest more money. At the moment, she does not manage to save up for that, because her husband takes what she saves to use on petrol for his motorbike, or for other personal needs. He wants to know what she is doing, but never helps her with the planning or the actual work.

\section{D : Plastic sandals for the suburbs}

D. is 30 years old. She lives with her husband and their 3 year old son in her father's compound, which he acquired in 1977. D. is born in Bamako, but her parents immigrated from Senegal before independence. Both her parents and several of her siblings are traders. Her husband is trained as an accountant, but is currently out of work. He also has some skill as an electrician, and spends most of his time away from home looking for odd jobs. He earns very little. They pay no rent, and eat with the extended family. Their occasional contributions to the common pot come from D's earnings rather than those of her husbands.

Two years ago, when he was still earning money regularly, her husband gave D 50.000 FCFA to establish herself in trade. She decided to buy plastic sandals and children's plastic shoes wholesale in the city and retailing them at a local, peripheral market within walking distance 
79.

from her home. She now has her own place at this market, where she goes every morning at 8 and stays until one o'clock. Sales are variable, but some days she has many customers and does quite well. She buys stock twice a month from the same supplier at the central market in town, usually in cash, and for about 30.000 FCFA at a time. Her mark up is 25 per cent on sandals and 30 per cent on children's shoes, and she sells about equal quantities of each. Her prices are fixed, and she sells on credit only when she is certain that she will recover her money soon. Her daily expenses are 50 FCFA for taxes and 25 for her location at the market. She goes to the market on foot, so her transport expenses are limited to the fortnightly trips into town to get new stock. Her sales approximate 80.000 CFA a month and her net profits are 18.000. She works for about 6 hours a day, a bit longer on the days when she goes to town to get supplies. She has no plans to expand her operation.

$D$ puts 500 FCFA daily into a savings society, where the money is redistributed every tenth day. If necessary, this goes to buy new stock. In principle, this money is hers to spend as she pleases. The rest of her earnings covers daily expenses for herself and the child.

\section{DISCUSSION}

These four women typify many features known from existing studies of the urban informal sector (see for instance Bromley \& Gerry 1979, Deblé \& Hugon 1982 and special issues of Revue Tiers Monde of 1980 and 1985). They all deal in everyday consumer goods, offering cheap products to poor clients. Since they all work at a quite small scale, they manage to handle the bulk of goods on their own and no storage space or extra transport facilities are needed. They also work on their own, in the sense that they are not under contract with anyone and do not employ others. Three are, however, dependent on unremunerated family labour, or more precisely child labour, in theit operations. There is little relation between time put in and economic reward. They all make contributions to the family budget, but the one who has the heaviest economic responsibilities, (B), works the hardest for 'he least money.

They are all illiterate, and do their business without any formal accounting. But apart from B., who often is forced to use unsold wares for food, they all are in control of what they are doing. They manage to put money aside for new stock and have no problems in describing the details of their outlays and profits. This is in contrast to stereotypes found in much of the literature on small-scale women traders. Such women are often described as having so varied and small sources of income that they have little idea of the size of their operation. Using proceeds for immediate daily consumption, often forced to sell their goods at a loss, they are rarely able to keep in business on a regular basis. These four women are perhaps exceptional in how they are able to give information about their day-to-day expenses and sales. But it is also possible that earlier generalizations have been too hastily drawn. 
80.

D. stands apart as doing only trade, buying and retailing. She is also the only one selling industrial products, and in a field which is not particularly female dominated. In fact, shoeselling both at the central market in Bamako, at sidewalks and at the peripheral markets is as often done by men as by women. The three others do not only trade, but processing what they sell is the basis of their income. This takes place at their own home, often in combination with housework and child-care. The skills they employ are related to the tasks they have as housewives, and their economic operations may be seen as an extension of their

domestic role. Their home compound is essential in their operations. It is also noteworthy how relationships to business contacts are personalized: A avoids paying tax because she knows the tax-collector, B gets credit from her supplier of fire-wood because they come from the same village, $\mathrm{C}$ has already build up a network of clients among her neighbours, with the help of her daughter.

From the data at hand, it is difficult to assess how viable their operations are over time. A stands out as the most enterprising but also the one who is least dependent on her business activities to meet her daily needs. B seems to be caught in a downward spiral of not making ends meet. Unless her eldest son and daughter manage to help her better, it seems likely that her other children will have to be fostered out and the family unit be dissolved. C's success is dependent on her husband's allowing her more freedom and on the market for homemade soap not getting glutted. D is the most professional, who has the support of both her husband and her own kin. But the competition in selling plastic shoes is fierce, so continued success is probably dependent on remaining on small scale at the local market.

Apart from D, these women would in all probability not be counted as economically active in censuses and labour force surveys, unless a special effort was made to get information from women themselves and not only from male heads of households. These men would probably describe them as "doing a little trade", and label them as housewives. In the West African cultural setting, where men and women have to a large degree separate economies, and where how much money one makes is often kept as a secret from one's spouse, the men simply do not know enough about the economic activities of their wives to give reliable information about them. It is in the women's interest to keep how much they earn to themselves. The more they can get from their husbands for food, the freer they are to use their own income to build up security through investment in their children, and in savings and friendships. They are in the black economy in a double sense, their activities are not only unregistered and unrecognized, but what they make is also unknown to almost everybody but themselves.

If we are to improve our understanding of the urbanization process currently taking place in Third World countries and how people manage to survive in the cities, it is essential to have a more realistic assessment of women's economic activities, of the role of unremunerated family labour and of children's work than official statistics now give. This represents a challenge to researchers from several disciplines, and to practitioners in planning agencies and other branches of administration. 
81.

The purpose of this paper has partly been to bring more coal to this fire. There is probably no direct route from detailed case studies of this type to new and improved procedures in the collection of economic statistics. Case studies usually are done for other purposes, such as understanding household viability, changes in family structure, or, as in the project from which these cases are drawn, women's survival strategies in urban poverty. But such studies also serve in the development of new and more valid categories of the economic base of households, and indeed, of cities. The variety of ways new urbanites are dealing with the challenge of making ends meet is also a fascinating subject in its own right. Their inventiveness and industry cannot be captured without studying them at close hand.

But if we ask about "occupation" and "income", we are likely to get "housewife" and "none" for answers. Western concepts cannot be directly translated to give a valid description of other realities. An African housewife is both an administrator and a producer, in addition to cooking and cleaning and looking after other peoples' well-being. When earning money, she would nevertheless consider herself without an income unless she is somebody's employee. What she makes is often used to pay for things already consumed, or for family emergencies. It does not make much sense to her to add up these sums into an abstract notion of "monthly income", an amount of money she never gets her hand on. In order to understand what is going on, we must seek our data from description of activities rather than insisting on our own abstract categorizations in posing questions to informants. Most people know very well what they are doing. As researchers, part of our task is to get them to describe it in a way which is meaningful both for us and for them.

\section{NOTES}

1) This paper was prepared without access to the results from the 1987 Census. The final report from the project will contain a more detailed discussion of how census data, economic statistics and special surveys from Bamako present women in the work force. 
82.

\section{REFERENCES}

Antoine, Antoine \& Aminata Traoré : "Pour une lisibilité du rôle des femmes à travers les données statistiques" in ORSTOM 1985

Beneria, Lourdes : "Conceptualizing the Labor Force : The Underestimation of Women's Economic Activities" in Nelson 1981

Bromley, Ray \& Chris Gerry (eds) : Casual Work and Povertv in Third World Cities. New York 1979

Charmes, Jacques : "Les statistiques de l'emploi et de la production occultent-elles l'activité économique des femmes en Afrique ?" in ORSTOM 1985

Deblé, Isabelle \& Philippe Hugon (eds) : Vivre et survivre dans les villes africaines I.E.D.E.S, Collection Tiers Monde Presses Universitaires de France, Paris 1982

ISH : Exode des Femmes au Mali. Institut des Sciences Humaines, Bamako 1984

Keita, Rokiatou Ndiaye : Les indicateurs socio-économiques de l'intégration des femmes au développement :cas du Mali ONU, Commission Economique pour l'Afrique. Série de Recherche, Addis Abeba 1981

Lambert de Frondeville, Agnès : "Une alliance tumultueuse, les commerçantes maliennes du Dakar-Niger et les agents de l'Etat" Cahiers de l'ORSTOM. Série Sciences Humaines, $1987 \mathrm{n}^{\circ} 2$ 
83.

Nelson, Nici, (ed) : African Women in the Development Process, Frank Cass, London 1981

Obbo, Christine : African Women, their Struggle for Economic Independence. Zed Press, London 1980

O'deye, Michèle : Les associations en villes africaines : Dakar-Brazzaville, l'Harmattan, Paris 1985

Oppong, Christine : Female and Male in West Africa, Allen \& Unwin, Boston-Sydney-London 1983

ORSTOM : Femmes et politiques Alimentaires Actes du Séminaire International ORSTOM CIE 14-18 Janvier 1985, Paris, Editions de l'ORSTOM Paris 1985

PUM : Etude du développement urbain de Bamako Programmation décennale des investissements, Etudes Générales Rapport Socio-économique, République du Mali, Ministère de l'Intérieur, Direction du Projet Urbain du Mali (PUM), Bamako 1984

Revue Tiers Monde : Secteur informel et petite production marchande dans les villes du Tiers Monde, Tome XXI, $\mathrm{n}^{\circ}$ 82, Avril-Juin 1980

Revue Tiers Monde : La sortie du travail invisible : Les femmes dans l'économie, Tome XXVI $n^{\circ} 102$, avril-juin 1985

UNICEF : Analvse de Situation: Femmes et Enfants au Mali, L'Harmattan, Paris 1989

Vaa, Mariken : "Urban growth and Urban Poverty : Women's Strategies for Survival in Bamako, Mali". Working Paper n' 5 1987, Institute for Social Research, Oslo 1987 
84.

Vaa, Mariken, Diallo Assitan \& Sally Findley : "The Gift Economy:

A study of women migrants' survival strategies in a low-income Bamako neighbourhood". Paper presented at the IUSSP Conference on "Women's Position and Demographic Change in the Course of Development", Asker, Norway 15-18 June 1988. Revised version in press, Labour. Capital and Society. 